\title{
Small heat shock proteins genes are differentially expressed in distinct varieties of common bean
}

\author{
Jean Luiz Simões-Araújo ${ }^{1,2 *}$, Norma Gouvêa Rumjanek ${ }^{1}$ and Márcia Margis-Pinheiro ${ }^{2}$
}

\author{
${ }^{1}$ Embrapa-Agrobiologia - BR 465, Km 47 (Antiga Estrada Rio São Paulo), CP 74505, CEP 23851-970, Seropédica, RJ, Brasil; \\ ${ }^{2}$ Laboratório de Genética Molecular Vegetal - Departamento de Genética Universidade Federal do Rio de Janeiro CP 68011, CEP \\ 21941-970, Ilha do Fundão, Rio de Janeiro, RJ, Brasil; * Corresponding author: jean@cnpab.embrapa.br \\ Received: 18/11/2002, Accepted: 09/12/2002
}

Plants respond to temperature stress by synthesizing a set of heat shock proteins (HSPs), which may be responsible for the acquisition of thermotolerance. In this study, the induction of small HSPs (sHSPs) in eight common bean varieties was evaluated by Northern blot analysis using the W HSP 16.9 cDNA as heterologous probe. Cowpea was used, as a positive control since this plant, as opposed to common bean, is known to grow well under high temperature regimes such as that found in the Brazilian semi-arid region. After the growth period, the plants were submitted to two h of heat shock at $40{ }^{\circ} \mathrm{C}$. All varieties tested were able to induce sHSP mRNAs that hybridized with W HSP 16.9 probe. However, significant kinetic differences were found when comparing different varieties. SHSP mRNA levels induced after heat shock in cowpea was higher than the levels observed on the bean varieties displaying the highest expression of these proteins. Besides, the sHSP expression was also assessed at the protein accumulation level by Western-blot analysis for cowpea and both IPA 7 and Negro Argel varieties of bean plants. The revealed protein pattern confirmed that sHSPs are differentially expressed in distinct varieties of common bean according their heat stress tolerance.

Key words: common bean, heat shock proteins, HSPs, thermotolerance, temperature stress.

Expressão diferenciada de proteínas de choque térmico de baixo peso molecular em distintos cultivares de feijoeiro: As plantas respondem ao estresse provocado por temperaturas elevadas através da síntese de um grupo de proteínas denominadas proteínas de choque térmico (Heat Shock Proteins-HSPs) que estão associadas com a obtenção de termotolerância. Nesse estudo, foi avaliada a indução de proteínas de choque térmico de baixo peso molecular (sHSPs) em oito cultivares de feijoeiro através de "Northern blot" utilizando o cDNA da W HSP 16,9 como uma sonda heteróloga. Caupi foi utilizado como controle, uma vez que, ao contrário do feijoeiro, é uma espécie que se apresenta bem adaptada às condições de temperaturas elevadas como as observadas no Semi-árido brasileiro. Após um período de crescimento, as plantas foram submetidas a um período de duas horas de choque térmico a $40{ }^{\circ} \mathrm{C}$. Todas as variedades avaliadas foram capazes de induzir mRNAs para sHSP que hibridizou com a sonda W HSP 16,9. Entretanto, foi observada uma diferença significativa no padrão de indução entre as diferentes variedades. Os níveis de mRNA e sHSPs induzidos em caupi após o choque térmico foram bem maiores que os observados para as variedades de feijoeiro. Além disso, a expressão de sHSPs foi também avaliada em relação ao acúmulo de proteínas através da análise de "Western-blot" para caupi e as variedades de feijoeiro IPA 7 e Negro Argel. O padrão de proteínas observado confirma que as sHSPs são diferencialmente expressas em diferentes variedades de feijoeiro de acordo com a tolerância ao estresse térmico.

Palavras-chave: estresse térmico, feijão, HSPs, proteínas de choque térmico, termotolerância.

\section{INTRODUCTION}

Cells of several organisms induce a set of proteins, the heat shock proteins (HSPs), when exposed not just to high temperature but also to other stresses such as heavy metal contamination, water deficit and presence of pathogens among others (Vierling, 1991). Plants are 
generally submitted to different kinds of stresses because it is very uncommon that optimal environmental conditions are attended (Howarth and Ougham, 1993). In tropical areas where excesses of radiation are common, high air and soil temperatures tends to be the most important factor reducing plant growth and yield. Furthermore, under field conditions, high temperature stress is generally associated to reduced water supply, which limits plant productivity even more.

Induction of HSPs seems to be a universal response to temperature stress being observed on all organisms ranging from bacteria to human beings (Vierling, 1991; Parsell and Lindquist, 1993). A comparison of the response to heat stress in different organism has shown that it is highly conserved and the molecular mechanisms of HSP gene induction have many similarities among diverse eukaryotes. Furthermore, the major HSPs are highly homologous among distinct organisms (Vierling, 1991).

HSPs are generally designated by their approximate molecular weights in $\mathrm{kDa}$ as HSP110, HSP90, HSP70, HSP60 and Low Molecular Weight HSPs (15-30 kDa), designated small heat shock proteins (sHSP) (Vierling, 1991; Waters et al., 1996; Sun et al., 2002). Although plants synthesize a similar set of high molecular weight HSPs, most of the translation capacity is devoted to the synthesis of the sHSPs (Mansfield, 1987). As far as it is known, all plant sHSPs are encoded by six nuclear gene families, each gene family corresponding to proteins found in distinct cellular compartments: cytosol (class I and class II), chloroplast, endoplasmic reticulum, mitochondria and membranes (Waters et al., 1996). Higher plants have at least 20 sHSPs and same species may have up to 40 different sHSPs (Vierling, 1991). Under heat stress conditions, the level of expression of the class I sHSPs in soybean can reach more than $1 \%$ of the total cellular protein (Hsieh et al., 1992). The wide diversification and abundance of sHSPs in plants may reflect adaptation to temperature stress (Water, 1996).

Some sHSPs are also expressed in some cells under cyclic or developmental control (Hopf, 1992). In the absence of environmental stress, the sHSP expression in plants is restricted to certain stages of development such as embryogenesis, germination, pollen development, and fruit maturation (Sun et al., 2002). Although the total physiological functions of HSPs have not been completely understood, there is considerable evidence to show that the acquisition of thermotolerance is correlated with synthesis and accumulation of HSPs (Lin et al., 1984; Weng and Nguyen, 1992; Jinn et al., 1993; Schirmer et al., 1994; Park et al., 1996; Prändl et al., 1998; Ristic et al., 1998; Joe et al., 2000). There is, however, considerable variation in the patterns of HSP production among different species, and even among individuals of the same specie (Ristic et al., 1991; Wood et al., 1998).

The acquisition of thermotolerance appears to depend not only upon the synthesis of HSPs but also on their cellular localization (Lin et al., 1984; Chou et al., 1989; Heckathorm et al., 1999; Korotaeva et al., 2001). Three observations strengthen this hypothesis: (a) the induction of HSPs has been characterized as an extremely fast and intense response, (b) the induction of HSPs indicates that the organism is being submitted to stress condition and, (c) the synthesis of HSPs is correlated to the induction of tolerance to temperature in a wide variety of cells and organisms (Parsell and Lindquist, 1993).

Common bean (Phaseolus vulgaris) is an important food crop in tropical countries. However, common bean is especially sensitive to high temperatures and even short periods under high temperature may reduce plant growth (Lin and Markhart III, 1996), limit nodulation and dinitrogen fixation (Piha and Munns, 1987; HernandezArmenta, 1989) causing significant reduction of productivity. The synthesis of some HSPs was already detected in common bean. Vidal et al. (1993) isolated and characterized a HSP $70 \mathrm{kDa}$ related to mitochondria membrane, which plays a role as a molecular chaperone. Chrispeels and Greenwood (1987) using protein labeled with $\mathrm{L}-\left[{ }^{3} \mathrm{H}\right]$-leucin found a $90 \mathrm{kDa}$ and three sHSPs in common bean cotyledons submitted to $43{ }^{\circ} \mathrm{C}$. Süss and Yordanov (1986) suggested that the interaction of HSP 22 $\mathrm{kDa}$ with the chloroplast external membrane can influence the composition of the membrane and decrease its fluidity, probably increasing the efficiency of the ATP transport. In this case, expression of sHSPs would be fundamental for tolerance to high temperatures.

The study of induced changes by high temperature on gene activation, expression, transcription and translation may help to understand the ability of plants to tolerate environmental heat stress that often occur during the acclimation process (Howarth and Ougham, 1993; Bray, 1997). In this study, we have used an heterologous probe for Northern hybridization to determine the induction and 
accumulation of HSP mRNAs in different bean varieties submitted to heat stress. The goal was evaluate the tolerance of different common bean varieties to high temperature stress by analyzing their capacity of induction of bean sHSP expression.

\section{MATERIAL AND METHODS}

Plant material and growth conditions: Eight common bean (Phaseolus vulgaris L.) varieties were selected for this study according to previous experiments performed at Embrapa Agrobiologia (unpublished date) and to the work developed by Singh (1989), which classified bean varieties according to the cultivation region, growth habit, size and seed colors and type of the phaseolin protein (table 1). The following common bean varieties were used: IPA 7, Negro Argel, Jamapa, Chimaltenango negro, Flor de Mayo, Cacahuate, Cranberry and Canario. As cowpea (Vigna unguiculata) is known by its tolerance to several environmental stresses including high temperature, it was selected as an indicator of tolerance.

Common bean and cowpea (V. unguiculata cv. IPA 206) seeds were surface-sterilized with $\mathrm{HgCl}_{2}(1: 500)$ and then germinated on sterile water-agar $\left(15 \mathrm{~g} . \mathrm{L}^{-1}\right)$ for $3 \mathrm{~d}$ (Vincent, 1970). Soon after germination, each seedling was transferred to a plastic recipient $(200 \mathrm{~mL})$, containing vermiculite and sand (2:1) and maintained in a greenhouse at $28{ }^{\circ} \mathrm{C}$ with sterile nutrition solution (Norris and T'mannetje, 1964) during the growth period.

Heat shock treatment: Fourteen-days-old plants, grown at $28{ }^{\circ} \mathrm{C}$, were submitted to $2-4 \mathrm{~h}$ of heat shock treatment at
$40{ }^{\circ} \mathrm{C}$ in a growth chamber. Leaves were collected after 10 and $30 \mathrm{~min}$ and 1 and $2 \mathrm{~h}$ of stress. Following the end of the heat shock treatment $(2 \mathrm{~h})$, the plants were maintained at $28{ }^{\circ} \mathrm{C}$ for a recovery period of up to $4 \mathrm{~h}$ and leaves were again collected after every hour. The leaves were immediately frozen in liquid nitrogen and stored at $-70{ }^{\circ} \mathrm{C}$ until total RNA extraction.

RNA extraction and analysis: Total RNA was isolated from each sample of frozen tissue $(0.5 \mathrm{~g})$ by the method adapted from Ragueh et al. (1989). After grinding in liquid nitrogen, the material was resuspended in $0.6 \mathrm{~mL}$ of an extraction buffer (200 mM Tris, pH 7.0, 200 mM EDTA, 1 $\%$ SDS), submitted twice to extraction with 1 volume of phenol:chloform:isoamylalcohol $(25: 24: 1)$ and finally to extraction with $0.6 \mathrm{~mL}$ phenol. The aqueous phase was separated by centrifugation (10 min, 12,000 rpm). After extraction with phenol, $0.75 \mathrm{~mL}$ of $\mathrm{LiCl}\left(4 \mathrm{~mol}^{-\mathrm{L}^{-1}}\right)$ was added to the aqueous phase and the mixture was held overnight at $4{ }^{\circ} \mathrm{C}$. The precipitated RNA was pelleted by centrifugation (20 min, 12,000 rpm). The pellet was washed three times with ethanol (75\%) and resuspended in $50 \mu \mathrm{L}$ of sterile distilled water. The RNA concentration was determined by measuring absorbance at $260 \mathrm{~nm}$.

For Northern analysis, $20 \mu \mathrm{g}$ of total RNA of each sample was submitted to electrophoresis in formaldehydecontaining agarose gels $(1,5 \%)$ as described by Sambrook et al. (1989). After electrophoresis, RNA was blotted onto nitrocellulose membrane and hybridized with W HSP 16.9 cDNA clone labeled with $\left[{ }^{32} \mathrm{P}\right] \mathrm{CTP}$ as a probe. The hybridization signal intensities were quantified from the $\mathrm{X}$-ray film using a LKB Laser densitometer. The values in

Table 1. Main characteristics of the common bean varieties used.

\begin{tabular}{|c|c|c|c|c|c|}
\hline \multirow{2}{*}{$\begin{array}{l}\text { Common bean } \\
\text { variety }\end{array}$} & \multicolumn{2}{|c|}{ Seed } & \multirow{2}{*}{$\begin{array}{l}\text { Phaseolin } \\
\text { protein type }\end{array}$} & \multirow{2}{*}{$\begin{array}{l}\text { Growth } \\
\text { habit }\end{array}$} & \multirow{2}{*}{$\begin{array}{c}\text { Growth } \\
\text { Temperature }\left({ }^{\circ} \mathrm{C}\right)\end{array}$} \\
\hline & color & size & & & \\
\hline IPA $7^{\text {a }}$ & Cream & Media & - & Indeterminate, semi-climbing, III & 38 \\
\hline Negro Argel ${ }^{b}$ & Black & Small & - & Indeterminate, semi-climbing, III & - \\
\hline Jamapa $^{\mathrm{b}}$ & Black & Small & $\mathrm{S}$ & Indeterminate upright, erect II & 24 \\
\hline ChimaltenangroNegro ${ }^{b}$ & Black & Small & $\mathrm{S}$ & Indeterminate, climbing IV & 18 \\
\hline Flor de Mayo $^{b}$ & Pink & Media & $\mathrm{S}$ & Indeterminate, semi-climbing, III & 22 \\
\hline Cacahuate ${ }^{b}$ & Cream & Media & $\mathrm{T}$ & Indeterminate, semi-climbing, III & 18 \\
\hline Cranberry $^{b}$ & Cream & Media & $\mathrm{C}, \mathrm{H}$ & Indeterminate, semi climber III & 22 \\
\hline Canario $^{b}$ & Yellow & Media & $\mathrm{T}$ & Determinate prostrate, or upright, I & 22 \\
\hline
\end{tabular}

${ }^{a}$ Communicated by IPA-Empresa Pernambucana de Pesquisa Agropecuária; ${ }^{b}$ Singh (1989) 
"counts" $\left(1 / 8 \mathrm{~V} \cdot \mathrm{s}^{-1}\right)$ for each band were used to follow the mRNA accumulation kinetics. In order to compare the expression pattern of the different varieties, values were corrected by the intensity of ethidium bromide staining of the rRNA in the agarose gels, measured as described.

Protein extraction and analysis by western blot: After the heat shock treatment, total protein was extracted from each sample of frozen tissue $(0.5 \mathrm{~g})$ according to the method described by Lin et al. (1984). SDS-PAGE was performed using a V16 model cube from GibcoBRL and an electrophoresis power supply model Power Pac 300 (Bio$\mathrm{Rad})$. Total protein suspensions on aliquots were mixed with an equal volume of loading buffer $\left(0,1\right.$ mol.L $\mathrm{L}^{-1}$ Tris$\mathrm{HCl} \mathrm{pH} \mathrm{6.8,} \mathrm{4.1} \mathrm{M} \beta$-mercaptoethanol, 11.4\% SDS, $0.1 \%$ bromophenol blue) and loaded on 12.5 or $15 \%$ polyacrylamide gels. Electrophoresis was carried out at 35 $\mathrm{mA}$ for $2 \mathrm{~h}$ and at $180 \mathrm{~V}$ for a further $4 \mathrm{~h}$ period. Proteins were stained with Coomassie Brilliant Blue-R250.

The proteins separated by SDS-PAGE were electrophoretically transferred to a $0.45 \mu \mathrm{m}$ nitrocellulose membrane by means of a mini Protein II cell transfer apparatus for western blotting detection. The transference was performed in a transfer buffer $\left(0.025 \mathrm{mmol} . \mathrm{L}^{-1}\right.$ Tris$\mathrm{HCl}, 125 \mathrm{mmol}^{-1} \mathrm{~L}^{-1}$ glycine, $20 \%$ methanol, $\mathrm{pH} 8.3$ ) during $1 \mathrm{~h}$ at $100 \mathrm{~V}$. The membrane was incubated with $50 \mathrm{~mL}$ of blocking buffer (100 mmol.L $\mathrm{L}^{-1}$ phosphate buffer $\mathrm{pH} 7.0,5$ $\%$ nonfat dry milk). The specific anti-rice 16.9 sHSP (Jinn et al., 1993) was added to a final concentration of 1:1500 and incubation took place during $2 \mathrm{~h}$. The membrane was then washed 3 times with $40 \mathrm{~mL}$ of TBS and incubated for $1 \mathrm{~h}$ with anti-rabbit $\operatorname{IgG}$ coupled with alkaline phosphatase diluted to 1:500 in blocking buffer. The detection was performed by BCIP and NBT (Bio-Rad).

\section{RESULTS}

Kinetics of accumulation of HSP $m R N A s$ in different common bean varieties: The patterns of SHSP mRNA accumulation in response to heat stress were examined for 8 common bean varieties using Northern blot experiments. Cowpea was also used as a reference since this plant grows quite well under high temperature regimes. As no bean or cowpea sHSP cDNA is available to be used as an homologous probe, cDNA from a wheat heat shock protein with 16.9 kDa (McElwain and Spiker 1989), which in a previous experiment showed strong positive hybridization with common bean mRNA, was used to detect sHSP transcripts in both leguminous plants. The results indicate the existence of at least three different patterns of induction and accumulation of sHSP mRNAs when plants were submitted to $40{ }^{\circ} \mathrm{C}$ during $2 \mathrm{~h}$ (figures 1 and 2). The HSP mRNA induction was observed as soon as the plants were transferred to a $40{ }^{\circ} \mathrm{C}$ chamber, while maximum accumulation was observed after 1 to $2 \mathrm{~h}$ from the beginning of the heat shock. After $2 \mathrm{~h}$, the plants were transferred back to a green house where temperature was kept between 28 and $30{ }^{\circ} \mathrm{C}$. Plants were harvested for an extra period of $4 \mathrm{~h}$, during the recovery period when it was observed significant levels of mRNA hybridizing with W HSP 16.9 probe.

sHSP mRNAs were expressed within 10 min of heat shock at $40{ }^{\circ} \mathrm{C}$ for all varieties but not in Negro Argel (figure $1 \mathrm{~A}-\mathrm{I}$ ). After $30 \mathrm{~min}$ of heat shock, a continuous increase in the mRNA levels hybridizing with W HSP 16.9 was observed, the highest levels being reached for most of the varieties after $1 \mathrm{~h}$ of the heat treatment. Varieties Canario and Negro Argel showed the maximum level of transcript after $2 \mathrm{~h}$ of the heat shock treatment (figures $1 \mathrm{E}$ and $1 \mathrm{H}$ ). For cowpea plants, the maximum level of transcript was reached after 1 hour, which was maintained until the end of the heat shock treatment. Furthermore, for cowpea the transcript level accumulated was considerable higher than that observed for common bean varieties. On the other hand, for varieties Flor de Mayo, Cranberry and IPA 7 that showed the maximum level of transcript after $1 \mathrm{~h}$ of heat shock, a decrease in the sHSP mRNA level was observed after this period, although the heat shock was still being applied. After removing the plants from the 40 ${ }^{\circ} \mathrm{C}$ chamber, they were allowed to recover at $28{ }^{\circ} \mathrm{C}$ during $4 \mathrm{~h}$. The sHSP mRNA from common bean varieties reduced significantly after $2 \mathrm{~h}$ on the recovery temperature. This reduction was less accentuated for cowpea and Canario varieties.

The autoradiography of the Northerns blot membranes were scanned with a laser densitometer and the values corresponding to the intensities of W HSP 16.9 mRNA hybridization band were recorded. These values were plotted against time for each variety studied (figure 2). The different varieties could be arranged on three groups according to the pattern of steady state of sHSP mRNA levels reached in response to heat shock. Group 1 is 
represented by cowpea and the IPA 7 variety, which displayed the highest level of transcript accumulation (figure 2A). Group 2 (figure 2B) is represented by Cranberry, Canario and Cacahuate, which express intermediate transcript levels. Group 3 encompasses most of the common bean varieties and is characterized by a small amount of transcript formation that occurs during the first hour of heat treatment, disappearing quickly after that (figure 2C).

Accumulation of HSP in cowpea and in common bean. The patterns of sHSP accumulation in response to heat stress were determined for 2 common bean varieties and cowpea by western blot using the anti-rice sHSP 16.9 (Jinn et al., 1993). The antibody raised from 16.9 rice HSP crossreacts with sHSP of a large number of plant species including wheat, soybean, mung bean and others (Jinn et al., 1993). The sHSP mRNAs accumulated in the plant leaf tissues used in this experiment were also analyzed by Northern blot using the W HSP 16.9 cDNA (McElwain and Spiker, 1989). The results confirmed that for both cowpea and IPA 7 bean variety the patterns of sHSP mRNA accumulation are very similar, showing a maximum mRNA level after $2 \mathrm{~h}$ and a fast decrease after $4 \mathrm{~h}$ from the onset of the treatment. In contrast, Negro Argel bean variety presented a smaller but very stable accumulation level of the sHSP mRNA during the observed period (figure 3B). The western blotting analysis showed that the accumulation levels of sHSPs are higher in IPA 7 and cowpea than in Negro Argel, although, the protein amount in bean IPA 7 variety decreased faster than in cowpea. Besides that, cowpea presented, in addition to the $16.9 \mathrm{kDa}$ protein, a second band at $22 \mathrm{kDa}$ revealed by the anti-rice sHSP. For Negro Argel variety, there was a strict correlation between the accumulation pattern of sHSP mRNAs and the protein concentration when plants were submitted to the $40{ }^{\circ} \mathrm{C}$ shock treatment (figures $3 \mathrm{~A}$ and $3 \mathrm{~B}$ ).

The western blot analysis confirmed that cowpea and the IPA 7 bean variety, displayed the highest level of accumulation of sHSP while Negro Argel was characterized by a weak expression of this proteins (figure $3 \mathrm{~A}$ ).

\section{DISCUSSION}

The accumulation of sHSP mRNAs in cowpea and eight common bean varieties was evaluated by Northern blot using a heterologous probe W HSP 16.9 isolated from wheat (McElwain and Spiker, 1989). The percentage of
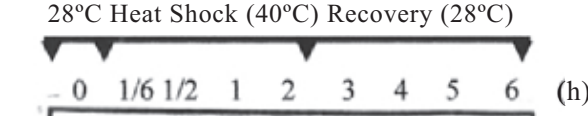

A)

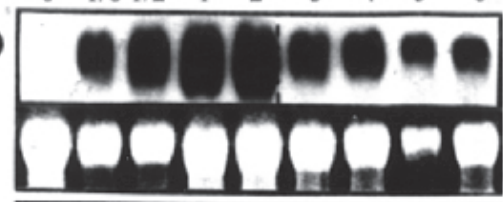

B)

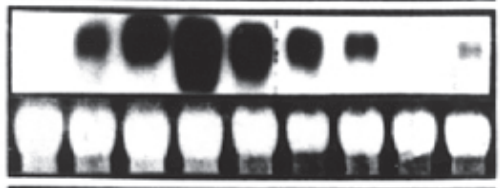

C)

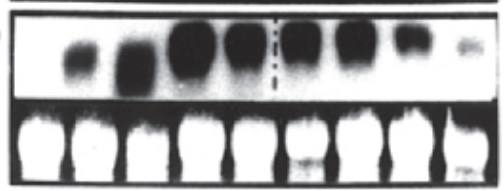

D)

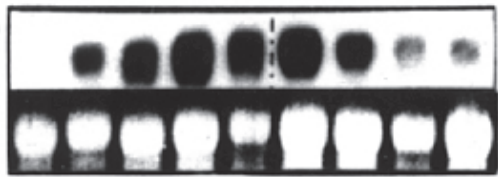

E)

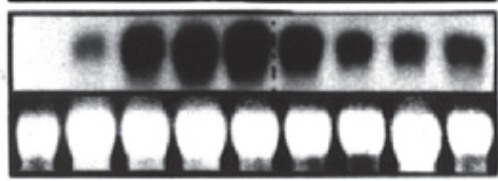

F)

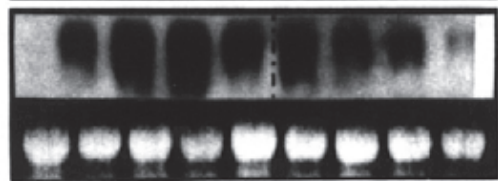

G)

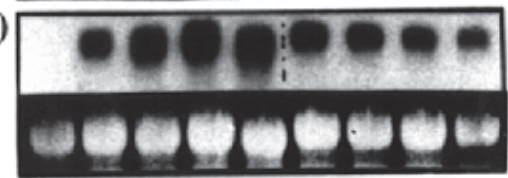

H)

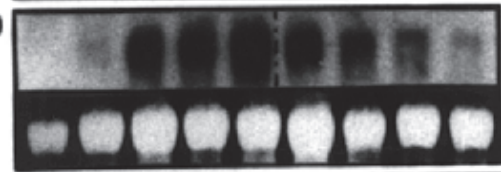

I)

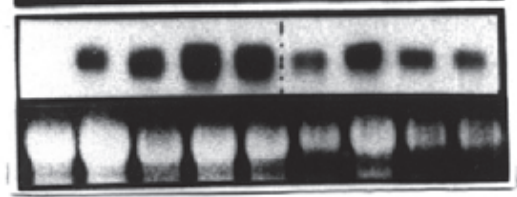

Figure 1. Accumulation of sHSPs during heat shock and recovery periods. Northern blot of total RNA from leaves of cowpea and different common bean varieties. The plants were submitted to heat shock at $40{ }^{\circ} \mathrm{C}$ up to $2 \mathrm{~h}$ and then transferred to $28^{\circ} \mathrm{C}$ up to $4 \mathrm{~h}$. The W HSP $16.9 \mathrm{cDNA}$ was used as probe. A) Cowpea, B) IPA 7, C) Cranberry, D) Cocahuate, E) Canario, F) Flor de Mayo, G) Chimaltenango Negro, H) Negro Argel, I) Jamapa. Lower panel: ethidium bromide staining of ribosomal RNAs to verify equivalency of mRNA loading. 
amino acid similarity among class I sHSPs, isolated from different species of plants, was shown to be very high reaching values over $90 \%$ (Jinn et al., 1993). Thus, it was not astonishing that heat shock stress was capable of inducing mRNA, which hybridizes with the heterologous probe, even under high stringency conditions, in all bean varieties used in this work. The analysis of sHSP mRNA accumulation showed considerable differences among the distinct bean varieties in response to heat shock. The transcripts were detected as soon as ten minutes after the beginning of the heat shock for most of the varieties, except for Negro Argel and Canario.
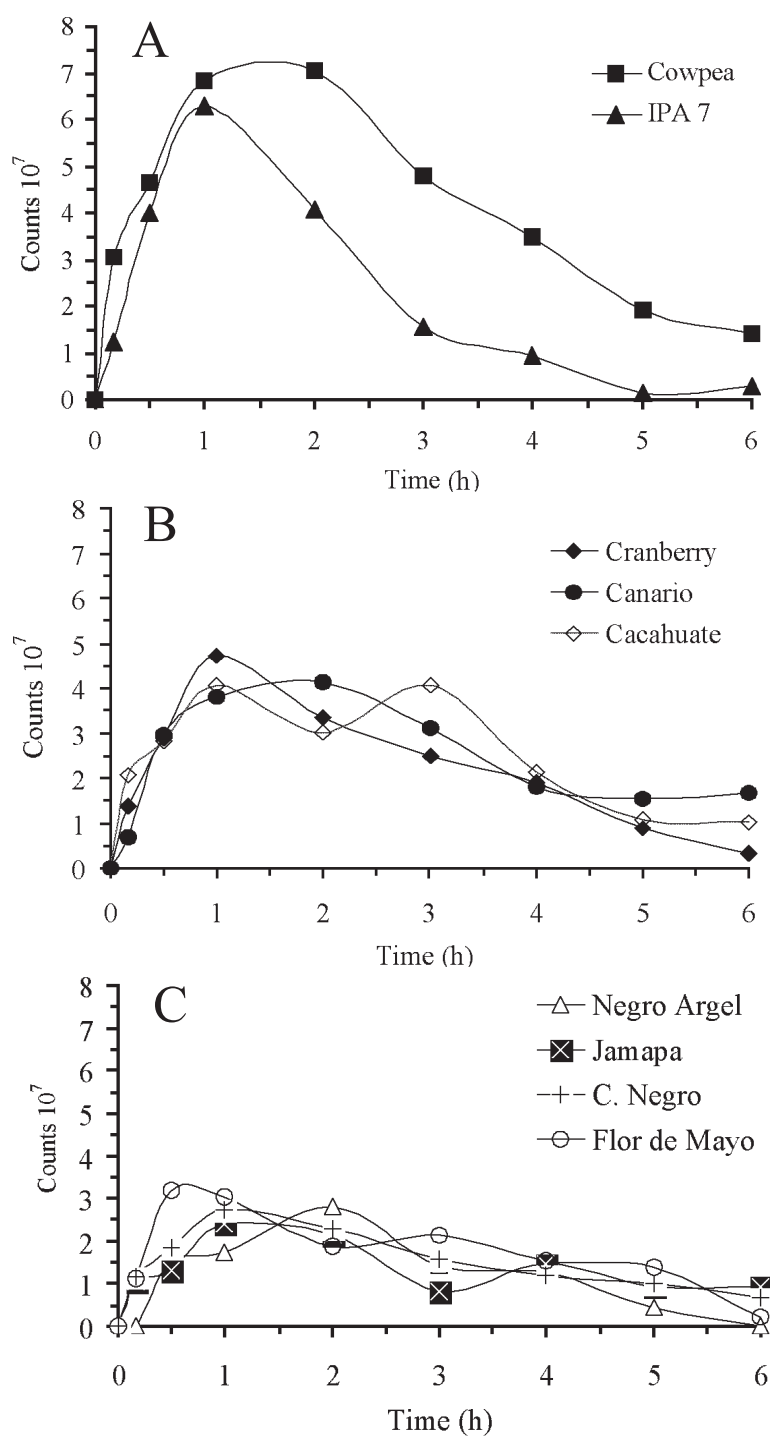

Figure 2. Kinetics of accumulation of sHSP mRNA during heat shock and further recovery period. Each value corresponds to the hybridization signal intensity from the Northern normalized by the values obtained from the rRNA both measured by densitometry.
The induction of sHSP in response to heat shock was previously observed in several species, such as wheat (Weng and Nguyen, 1992), pea (DeRocher et al., 1991; Lenne and Douce, 1994) and corn (Nieto-Sotelo et al., 1989). Lenne and Douce (1994) studied the sHPS gene expression in pea mitochondria and observed that the maximum accumulation of mRNA occurred within the first hour of treatment at $40{ }^{\circ} \mathrm{C}$. Similar results were also obtained by Nieto-Sotelo et al. (1989) when examining the levels of HSP 26 mRNA during heat shock treatment. Considering that the presence of sHSPs can prevent denaturation caused by high temperature (Jinn et al., 1993; Yeh et al., 1995) the fast accumulation of them could play an important role on the protection of the metabolic apparatus of the cell. Therefore, reduction of deleterious effects promoted by high temperature could be a key factor for organism adaptation under these conditions. Jinn et al. (1997) showed evidence that sHSPs are essential for acquisition of thermotolerance in two-day-old soybean seedlings. Recently, Malik et al. (1997a) have demonstrated that both carrot cell lines and tomato plants transformed with HSP 17.7, a small heat shock protein from carrot, exhibit increased thermotolerance. The same group also showed a substantially reduction on thermotolerance with cell lines that were expressing the antisense to the HSP 17.7 gene in relation to control cells. Analysis of the antisense transfected cells revealed that HSPs protein synthesis was reduced and the effect was even more intense with the low molecular weight class (Malik et al., 1997b).
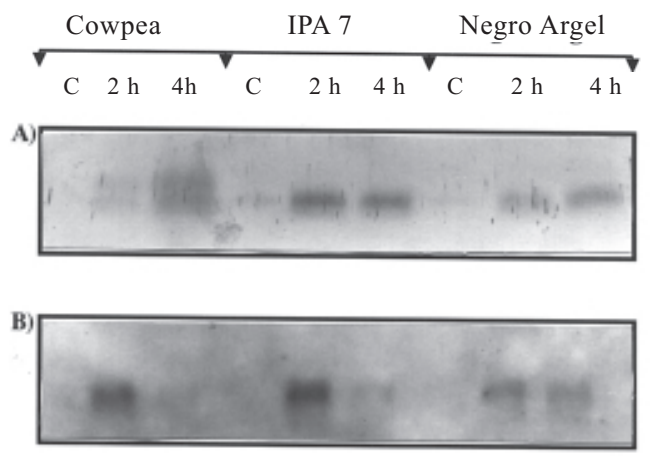

Figure 3. sHSP accumulation during heat shock. The plants were submitted to heat treatment at $40{ }^{\circ} \mathrm{C}$ for 2 and 4 h. The control plants were kept at $28^{\circ} \mathrm{C}$. (A) Western blot of total leaf protein from cowpea and two varieties of bean (IPA7 and Negro Argel). The anti rice sHSP 16.9 was used as specific antibody. (B) Northern blot of total RNA from the same plants used in "A". The W HSP 16.9 cDNA was used as probe. 
Some bean varieties studied here showed a reduction in the sHSP transcript level after the first hour of the heat shock despite of this treatment being still applied. Studies on pea also showed that, after a maximum HSP mRNA level has been reached, degradation of the transcripts became more intense than synthesis resulting in a decrease of the detected mRNA. Nevertheless this decreasing is not necessarily followed by a reduction in the protein level (Lenne et al., 1995). Differences in the kinetics of synthesis and degradation of HSPs and its mRNAs have been reported (Kimpel et al., 1990; Green, 1993). The results presented here suggest that sHSP mRNA half-life may be dependent on the bean genotype. The variety IPA 7 has the half-life of sHSP mRNAs limited to some hours. On the other hand, half-life for pea sHSP proteins can be as long as $52 \mathrm{~h}$ (DeRocher et al., 1991) and for soybean seedling more than $3 \mathrm{~d}$ (Jinn et al., 1997). The observed decrease on the HSP mRNA levels does not necessarily correlate with the HSP concentration (Apuya and Zimmerman, 1992). Nevertheless, our results from the western blotting analysis suggested that the sHSPs levels on the three genotypes studied; cowpea, bean IPA 7 and Negro Argel, are coordinated with the kinetics of mRNA accumulation, indicating that the major control point of sHSP expression corresponds to the transcriptional process. Despite the use of cDNA probe and antibody from different sources, wheat and rice, respectively, the antibody raised from $16.9 \mathrm{kDa}$ rice HSP cross-reacted with wheat sHSP (Jinn et al., 1993). Thus, we could expect that the bean proteins reacting with rice sHSP antibody belong to the same class revealed by the wheat sHSP cDNA.

The pattern of the mRNA accumulation during the recovery period shows substantial differences among the distinct bean genotypes. Cowpea and three bean varieties (Canario, Cacahuate and Jamapa) maintained a high quantity of transcripts after $4 \mathrm{~h}$ of recovering at $28{ }^{\circ} \mathrm{C}$. However, for the other varieties studied the transcript level decreased drastically as soon as the high temperature stress was removed. Among them, IPA 7 has a unique pattern, presenting a higher accumulation at the beginning of the temperature treatment, but the mRNA rapidly decrease after the end of this treatment. Varieties Flor de Mayo, Chimaltenango Negro, Jamapa and Negro Argel show a very low level of mRNA accumulation during the heat stress. Gurley and Key (1991) reported that mRNA stability is the main factor involved in the maintenance of HSP mRNA levels after the end of the stress period. Therefore, the results obtained during and after the stress period may suggest that mRNA stability can be modulated according to the bean variety analyzed.

Although the mechanisms by which HSPs provide thermotolerance are still unknown, the differences observed on the transcript and protein accumulation levels suggest that different varieties present distinct response to heat stress. The studies reported by Weng and Nguyen (1992) using different varieties of wheat showed that W HSP 16.9 and other HSPs probes were capable of hybridizing more intensively with thermotolerant varieties. In this work, we have used cowpea as a control since this leguminous plant can be cultivated under high temperature conditions. Although none of the bean varieties studied displayed a behavior similar to cowpea concerning sHSP mRNA accumulation, IPA 7 was considered to have the closest pattern. This variety was recently recommended for the Northeast region of Brazil where high temperature regimes prevail.

The parameters studied allowed the identification of three main groups of bean varieties regarding the level of mRNA induced by heat stress. One group is represented by variety IPA 7, which induces the highest level of HSP mRNAs during the stress period. Corroborating with this result, the IPA 7 variety is tolerant to high temperatures and recommended to be cultivated at $38^{\circ} \mathrm{C}$ (communicated by IPA-Empresa Pernambucana de Pesquisa Agropecuária, September, 1990). Varieties Cacahuate, Canaria, Cranberry and Flor de Mayo are representatives of a group with intermediate level of HSP mRNA induction, while Chimaltenango Negro, Jamapa and Negro Argel produce the lowest level of transcript during heat stress. All varieties from groups 2 and 3 present optimal growing temperature between 18 and $24{ }^{\circ} \mathrm{C}$ (table 1). Evans (1973) reported that a difference on thermotolerance among the varieties might be observed accordingly to the original domestication area. The varieties originated from the Meso-america region, showing predominantly growth habit types II and III, are more tolerant to high temperature than varieties originated from the Andean, characterized by growth habits I and IV well adapted to high altitudes and cold weather. The same pattern is described to lima bean (Phaseolus lunatus) cultivars where the Mesoamericam gene pool have greater adaptability to heat stress than cultivars from the Andean gene pool (Mackie, 1943, cited by Keeler et al., 2000). Among the varieties used in this study, three are from Mesoamerica region and two are from the Andea. In this work, varieties of Mesoamerica origin 
and habit type III, presented a higher induction of HSP mRNAs indicating a relationship between transcript production and thermotolerance.

Yield under heat stress may be affected by various aspects of the heat response, such as, the ability to detect temperature as stressful, the ability to response shifts quickly, the extent of the response, and the tissue specificity of the response (Keeler et al., 2000). The importance of the HSPs in the heat stress tolerance is still not completely understood but somehow they are involved on tolerance to several environmental stresses. In the literature, the response of bean plants to heat stress is still poorly represented and furthers studies are needed since the characterization of bean heat shock related genes and their expression might be an important contribution for the assisted selection of bean varieties adapted to tropical conditions.

Acknowledgments: The authors thank Dr. Robert M. Boddey (Embrapa-Agrobilogia) for critical reading of the manuscript, Dr. Steven Spiker (North Carolina University) and Dr. Chu-Yung Lin for providing W HSP 16.9 cDNA clone and rice LMW-HSP 16.9 antibody, respectively. We also thank Dr. Hélio Almeida Burity (IPA-Empresa Pernambucana de Pesquisa Agropecuária) for providing with information on bean variety IPA7. JLA and NGR are recipients of a fellowship from $\mathrm{CNPq}$ (Brazil).

\section{REFERENCES}

Apuya RA, Zimmerman JL (1992) Heat shock gene expression is controlled primarily at the translational level in carrot cells and somatic embryos. Plant Cell 4:657-665.

Bray E A (1997) Plant response to water deficit. Trends Plant Sci. 2:49-54.

Chou M, Chen YM, Lin CY (1989) Thermotolerance of isolated mitochondria associated with heat shock proteins. Plant Physiol. 89:617-21.

Chrispeels MJ, Greenwood JS (1987) Heat stress enhances phytohemagglutinin synthesis but inhibits its transport out of the endoplasmic reticulum. Plant Physiol. 83:778-84.

DeRocher EA, Helm KW, Lauzon LM, Vierling E (1991) Expression of a conserved family of cytoplasmic low molecular weight heat shock proteins during heat stress and recovery. Plant Physiol. 96:1038-47.

Evans D (1973) Ecologia do feijoeiro. In: Mariot EJ (ed), O feijoeiro no Paraná, pp.303. IAPAR, Londrina
Green PJ (1993) Control of mRNA stability in higher plants. Plant Physiol. 102:1065-70.

Gurley WB, Key JL (1991) Transcriptional regulation of heat-shock response: a plant perspective. Biochemistry 30:1-11.

Hernandez-Armenta R, Wien HC, Eaglesham ARJ, (1989) Carbohydrate partitioning and nodule function in common bean after heat stress. Crop Sci. 29:1292-97.

Hopf N, Plesofsky-Vig N, Brambl R (1992) The heat response of pollen and other tissues of maize. Plant Mol. Biol. 19:623-30.

Howarth CJ, Ougham HJ (1993) Gene expression under temperature stress. New Phytol. 125:1-26.

Hsieh MH, Chen JT, Jinn TL, Chen YM, Lin CY (1992) A class of soybean low molecular weight heat shock proteins, immunological study and quantification. Plant Physiol. 99:1279-84.

Jinn TL, Wu SH, Yeh KW, Hsieh MH, Yeh YC, Chen YM, Lin CY (1993) Immunological kinship of class I low molecular weight heat shock proteins and thermostabilization of soluble proteins in vitro among plants. Plant Cell Physiol. 34:1055-62.

Jinn TL, Chang PFL, Chen YM, Key JL, Lin CY (1997) Tissuetype-specific heat-shock response and immunolocalization of class I low-molecular-weight heat-shock proteins in soybean. Plant Physiol. 114:429-38.

Joe MK, Park SM, Lee YS, Hwang DS, Hong CB (2000) High temperature stress resistance of Escherichia coli induced by a tobacco class I low molecular weight heatshock protein. Mol. Cells. 10:519-524.

Keeler SJ, Boettger CM, Haynes JG, Kuches KA, Johnson MM, Thureen DL, Keeler jr. CL, Kitto SL (2000) Acquired thermotolerance and expression of the HSP100/ClpB genes of bean Lima Bean. Plant Physiol. 123:1121-1132.

Kimpel JA, Nagao RT, Goekjian V, Key JL, (1990) Regulation of the heat shock response in soybean seedlings. Plant Physiol. 94:988-95.

Lenne C, Blocks M A, Garin J, Douce R (1995) Sequence and expression of the mRNA encoding hsp22, the mitochondrial small heat shock protein in pea leaves. Biochem. J. 311:805-813.

Lenne C, Douce R (1994) A low molecular mass heat-shock proteins is localized to higher plant mitochondria. Plant Physiol. 105:1255-61.

Lin CY, Roberts JK, Key JL (1984) Acquisition of thermotolerance in soybean seedling, synthesis and accumulation of heat shock proteins and their cellular localization. Plant Physiol. 74:152-60. 
Lin TY, Markhart III AH (1996) Phaseolus acutifolius A. Gray is more heat tolerant than P. vulgaris L. in the absence of water stress. Crop Sci. 36:110-114.

Malik MK, Slovin JP, Zimmerman JL (1997a) Antisense to a sheat shock protein (HSP17.7) reduces acquired thermotolerance in carrot. Plant Physiol. 114 (Suppl):112.

Malik MK, Slovin JP, Zimmerman JL(1997b) Carrot cell lines and tomato plants transformed with a small heat shock protein from carrot (HSP17.7) exhibit increased thermotolerance. Plant Physiol. 114(Suppl):112.

Mansfield MA, Key JL (1987) Synthesis of the low molecular weight heat shock proteins in plants. Plant Physiol. 84:1007-1017.

McElwain EF, Spiker S (1989) A wheat cDNA clone with is homologous to the $17 \mathrm{kd}$ heat-shock protein gene family of soy bean. Nucleic Acids Res. 17:1764.

Nieto-Sotelo J, Vierling E, Ho DTH (1989) Cloning, sequence analysis, and expression of a cDNA encoding a plastidlocalized heat shock protein in maize. Plant Physiol. 93:1321-1328.

Norris DO, T'mannetje L (1964) The symbiotic specialization of African Thifolium spp. in relation to their taxonomy and their agronomic use. East African Agric. Forest. J. 29:214-235

Parsell PA, Lindquist S (1993) The function of heat-shock proteins in stress tolerance: degradation and reactivation of damaged proteins. Annu. Rev. Genet. 27:437-496.

Park SY, Shivaji R, Krans JV, Luthe DS (1996) Heat-shock response in heat-tolerance and nontolerant variants of'Agrostis palustris huds. Plant Physiol. 111:515-524.

Piha MI, Munns DN (1987) Sensitivity of common bean (Phaseolus vulgaris L.) symbioses to high soil temperature. Plant Soil 98:183-194.

Prandl R, Hinderhofer K, Eggers-Schumacher G, Schoffl F. (1998) HSF3, a new heat shock factor from Arabidopsis thaliana, derepresses the heat shock response and confers thermotolerance when overexpressed in transgenic plants. Mol. Gen. Genet. 258:269-278.

Ragueh F, Lescure N, Roby D, Marco Y (1989) Gene expression in Nicotiana tabacum in response to compatible and incompatible isolates of Pseudomonas solonaciarum. Physiol. Mol. Plant Pathol. 35:23-33.

Ristic Z, Gifford DJ, Cass DD (1991) Heat shock proteins in two lines of Zea mays L. that differ in drought and heat response. Plant Physiol. 97:1430-1434.
Sambrook J, Fritsch EF, Manniats T (1989) Molecular cloning: A Laboratory Manual. Cold Spring Harbour, New York.

Ristic Z, Yang GP, Martin B, Fullerton S (1998) Evidence of association between specific heat-shock protein(s) and the drought and heat tolerance phenotype in maize. J. Plant Physiol. 153:497-503.

Schirmer EC, Lindquist S, Vierling E (1994) An Arabidopsis heat shock protein complements a thermotolerance defect in yeast. Plant Cell 6:1899-1909.

Singh SP (1989) Patterns of variation in cultivated common bean (Phaseolus vulgaris, Fabeaceae). Econ. Bot. 43:39-57.

Sun W, Motangu MV, Verbruggen, N (2002) Small heat shock proteins and stress tolerance in plants. Biochim. Biophys. Acta 1577:1-9

Süss KH, Yordanov IT (1986) Biosynthetic cause of in vivo acquired thermotolerance of photosynthetic light reactions and metabolic response of chloroplasts to heat stress. Plant Physiol. 81:192-9.

Vidal V, Ranty B, Dillenschneider M, Charpenteau M, Ranjeva R (1993) Molecular characterization of a $70 \mathrm{KDa}$ heatshock proteins of bean mitochondria. Plant J. 3:143-150.

Vierling E (1991) The role of heat shock proteins in plants. Annu. Rev. Plant Physiol. Plant Mol. Biol. 42:579-620.

Vincent JM (1970) A manual for the practical study of rootnodule bacteria. International Biological Programmer, IBP handbook, n.15. Scientific Publications, Blaclkwell, Oxford.

Waters ER, Lee GJ, Vierling E (1996) Evolution, structure and function of the small heat shock proteins in plants. J. Exp. Bot. 47:325-38.

Weng J, Nguyen HT (1992) Differences in the heat-shock response between thermotolerant and thermosusceptible cultivars of hexaploid wheat. Theor. Appl. Genet. 84:941-6.

Wood CK, Pratt JR, Moore AL (1998) Identification and characterisation of cultivar-specific $22-\mathrm{kDa}$ heat shock proteins from mitochondria of Pisum sativum. Physiol. Plant. 103:369-376.

Yeh CH, Yeh KW, Wu SH, Chang PFL, Chen YM, Lin CY (1995) A recombinant rice 16.9-kda heat shock proteins can provide thermoprotection in vitro. Plant Cell Physiol. 36:1341-8. 